\title{
Phytochemical screening and cytotoxic evaluation of Bauhinia scandens leaf extracts using HeLa and T47D cell lines
}

\author{
LIANAH LIANAH ${ }^{1, \boldsymbol{v}}$, RITA ARIYANA NUR KHASANAH ${ }^{\mathbf{1}}$, DWIMEI AYUDEWANDARI PRANATAMI ${ }^{\mathbf{1}}$, \\ KRISANTINI KRISANTINI ${ }^{2}$ \\ ${ }^{1}$ Department of Biology, Faculty of Science and Technology, Universitas Islam Negeri Walisongo. J1. Prof. Hamka, Tambakaji, Ngaliyan, Semarang \\ 50185, Central Java, Indonesia. Tel.: +62-24-76433366, ^email: lianahk58@ gmail.com \\ ${ }^{2}$ Department of Agronomy and Horticulture, Faculty of Agriculture, Institut Pertanian Bogor. Jl. Meranti, IPB Darmaga Campus, Bogor 16680, West \\ Java, Indonesia
}

Manuscript received: 14 October 2020. Revision accepted: 20 January 2021.

\begin{abstract}
Lianah L, Khasanah RAN, Pranatami DA, Krisantini K. 2021. Phytochemical screening and cytotoxic evaluation of Bauhinia scandens leaf extracts using HeLa and T47D cell lines. Biodiversitas 22: 913-919. The aim of the study was to analyze the phytochemical contents and todetermine the cytotoxic activities of Bauhinia scandens leaf ethanol extracts against HeLa (human cervical cancer) and T47D (breast cancer) cell culture lines. Using a standard protocol, it was found that leaf extract of $B$. scandens contains phytochemicals that are widely known to have medicinal properties, such as phenols $(17.57 \pm 0.098 \% \mathrm{w} / \mathrm{w})$, flavonoids $(5.91 \pm 0.098 \% \mathrm{w} / \mathrm{w})$, saponins $(19.42 \pm 0.091 \% \mathrm{w} / \mathrm{w})$, tannins $(1.24 \pm 0.035 \% \mathrm{w} / \mathrm{w})$, alkaloids $(1.31 \pm 0.001 \%$ w/w $)$ and steroids $(0.08 \pm 0.007 \% \mathrm{w} / \mathrm{w})$. Results of 24-hr Microculture Tetrazolium Salt (MTT) assay show that leaf extracts of $B$. scandens can suppress cell growth at a half-maximal inhibitory concentration (IC50) of $1.95 \mu \mathrm{g} / \mathrm{mLfor}$ HeLa cells and $4.54 \mu \mathrm{g} / \mathrm{mL}$ for T47D cells. This indicates that $B$. scandens is a potentially strong candidate for anti-cancer agents. The cytotoxic activities of the leaf extracts of $B$. scandens can be attributed to the total effects of the phytochemical compounds found. Further studies are recommended in order to isolate and determine individual effects of bioactive compounds in B. scandens.
\end{abstract}

Keywords: Bauhinia, cytotoxicity, HeLa cells, phytochemicals, T47D cells

\section{INTRODUCTION}

Cervix and breast cancers are two of the topmost leading causes of death in the world (Indonesian Ministry of Health, 2019). Concerted efforts to manage cancers have led to various current treatments including chemotherapy, drugs, and radiotherapy, all of which adversely affect healthy cells to various extents. Another alternative way to manage cancer is through ethnomedicinal approaches. The use of alternative herbal medicine has been widely practiced by people worldwide to treat all kinds of diseases for a long time (Faisal et al. 2019). A diversity of plants around the world is now being studied and explored for their medicinal properties because of their phytochemical content.

Bauhinia is composed of 250 species of trees, shrubs, and climbers from the family Leguminosae. Several species of Bauhinia are used in traditional medicine (Hazra and Chatterjee 2008). Leaves of $B$. monandra, for example, contain phytochemicals with anti-nociceptive and antiinflammatory activities (Campos et al. 2016) while leaves of $B$. variegate have anti-bacterial, antitumor, and anticancer properties (Pandey 2017; Mishra et al. 2013, Singh et al. 2019). Leaves of $B$. purpurea also have antiinflammatory properties (Shreedhara et al. 2009), while the leaves of $B$. variegata were found to be effective for treating snakebites (Roy et al. 2008). Another study reported the bark of $B$. racemosa is known to provide analgesic remedies (Borikar et al. 2009).
Bauhinia scandens is a well-known legume species, which is well dispersed in Indonesia (Java, Madura, Sumatera, Sumba), Bangladesh, Bhutan, Cambodia, China (Hainan), India, Laos, Myanmar, Nepal, Thailand, and Vietnam (Bandyopadhyay and Lakshminarasimhan 2017). It is a woody climbing plant with height ranging from 30 to $50 \mathrm{~m}$ and possesses reverse tendrils (Lianah 2016). The young stems are green to brownish, while the old stems are darker with a variety of shapes, such as flattened, wavy, and resembling monkey staircases (Lianah et al. 2019). The young leaves are reddish, while the old leaves are green. The leaf laminas vary in shape from cordate, ovate to acute or emarginate, to deeply bilobed, sometimes almost to the base. The curved leaves have a heart-shaped base, flat edges, and tapered ends that split in half and they generally consist of 5-7 nerves. Bauhinia scandens grow well at an altitude of 500-800 m above sea level (Hou and Larsen 1996). Despite its wide distribution in Indonesia, there is limited information regarding the phytochemical properties and medicinal value of $B$. scandens. Previous studies showed that its leaves have non-toxic antitumor properties and antioxidant activities (Maitra et al. 1991; Hazra and Chatterjee 2008; Hossain et al. 2017). Therefore, the aim of the study was to analyze the phytochemical content of $B$. scandens leaves. Additionally, we would like to understand the medicinal properties of this species by investigating the cytotoxic activities of the leaf ethanolic extract against HeLa and T47D cell culture lines. 


\section{MATERIALS AND METHODS}

\section{Research design and sample preparation}

Two kilograms of young and mature leaves of $B$. scandens were collected in May 2018 and July 2019 from trees growing in the cemetery of Tugerejo, Ngaliyan Regency, Semarang, Central Java, Indonesia. The leaves were cleaned using running water and dried for 2 weeks at room temperature. Leaves were crushed and dissolved in $96 \%$ ethanol for 2 days to obtain about $1.8 \mathrm{~L}$ solution with a $\mathrm{pH}$ of 6.3 , dark green coloration, and rancid smell. The solution was transferred to a rotary evaporator $\left(60^{\circ} \mathrm{C}, 60\right.$ rpm) and evaporated for 7 hours, obtaining a viscous black solution, which was then air-dried.

\section{Qualitative phytochemical analysis}

Bauhinia scandens extract (hereafter referred to as sample extract) was analyzed qualitatively by standard procedures of metabolic identification as described by Sofowora (1993), Trease and Evans (1989), and Harborne (1973).

\section{Detection of flavonoids}

Three $\mathrm{ml}$ of $1 \%$ aluminum chloride solution was added into $1 \mathrm{ml}$ of sample extract, followed by $5 \mathrm{~mL}$ of dilute ammonia and concentrated $\mathrm{H}_{2} \mathrm{SO}_{4}$. Yellow coloration confirmed the existence of flavonoids.

\section{Detection of saponins}

One $\mathrm{ml}$ of sample extract was boiled in $20 \mathrm{ml}$ of distilled water and filtered, then $10 \mathrm{~mL}$ of the filtrate was mixed with $5 \mathrm{~mL}$ of distilled water, and shaken vigorously. The formation of a stable froth at least for $10 \mathrm{~min}$ indicated the existence of saponins.

\section{Detection of tannins}

One $\mathrm{ml}$ of sample extract was added to $20 \mathrm{ml}$ distilled water, and then filtered. A little drop of $0.1 \%$ ferric chloride $\left(\mathrm{FeCl}_{3}\right)$ was added. The formation of blackish-blue color confirmed the existence of tannins.

\section{Detection of alkaloids}

One $\mathrm{ml}$ of sample extract was stirred with 5 drops of $1 \%$ aqueous $\mathrm{HCl}$ on a steam bath, and filtered when it was in hot condition. Afterward, $1 \mathrm{ml}$ of the filtrate was tested with a few drops of Hager's reagent (picric acid). The formation of yellow precipitate confirmed the existence of alkaloids.

\section{Detection of terpenoids}

One $\mathrm{mL}$ of sample extract was mixed with $2 \mathrm{~mL}$ of chloroform. Subsequently, $3 \mathrm{~mL}$ of concentrated $\mathrm{H}_{2} \mathrm{SO}_{4}$ was carefully added to form a layer. The formation of a reddish-brown coloration confirmed the existence of terpenoids.

\section{Detection of steroids (Salkowski test)}

The acetic anhydride $(2 \mathrm{~mL})$ was added to $1 \mathrm{~mL}$ of sample extract, followed by the addition of $2 \mathrm{~mL}$ of $\mathrm{H}_{2} \mathrm{SO}_{4}$.
The yellow fluorescent coloration confirmed the existence of steroids.

\section{Detection of glycosides (Keller-Kiliani test)}

One $\mathrm{mL}$ of sample extract was mixed with $2 \mathrm{~mL}$ of acetic acid containing 1-2 drops of $2 \% \mathrm{FeCl}_{3}$, followed by the addition of $2 \mathrm{~mL}$ concentrated $\mathrm{H}_{2} \mathrm{SO}_{4}$. The formation of a reddish-brown color confirmed the existence of glycosides.

\section{Quantitative phytochemical analysis \\ Determination of flavonoid content}

One hundred mg of sample extract was mixed with 0.3 $\mathrm{mL}$ of sodium nitrite, and $0.6 \mathrm{~mL}$ of aluminum chloride. Two $\mathrm{mL}$ of $1 \mathrm{M}$ sodium hydroxide was added to the mixed solution obtained. The volume was made up to $10 \mathrm{~mL}$ using distilled water. The resulting solution was diluted (10 times) before the absorbance was read by UV-Vis spectrophotometer (Shimadzu UV-1800) at a wavelength of $510 \mathrm{~nm}$ (Baba and Malik 2014). A standard curve was obtained from diluted concentrations of quercetin under the same conditions.

\section{Determination of saponin content}

Fifty $\mathrm{mg}$ of sample extract was added to $2 \mathrm{~mL}$ concentrated $\mathrm{H}_{2} \mathrm{SO}_{4}$, and autoclaved $\left(110^{\circ} \mathrm{C}\right)$ for 120 minutes. Sample extract was re-extracted with ether, filtered, and dried. One $\mathrm{mL}$ water was added to the extraction, vortexed for $5 \mathrm{~min}$ before $50 \mu \mathrm{l}$ anisic aldehyde was added to the solution, then shaken for $10 \mathrm{~min}$, filtered, $2 \mathrm{~mL} 50 \% \mathrm{H}_{2} \mathrm{SO}_{4}$ was added before heating (water bath; $60^{\circ} \mathrm{C} ; 10 \mathrm{~min}$ ), and diluted 10 times with water. The absorbance was read with the spectrophotometer at $435 \mathrm{~nm}$ wavelength (Vador et al. 2012). A standard curve was obtained from some diluted concentrations of saponins isolated from Quillaja bark under the same conditions.

\section{Determination of tannin content}

Fifty $\mathrm{mg}$ of sample extract was diluted in $10 \mathrm{~mL}$ methanol for $20 \mathrm{hr}$, then filtered. Distilled water was added to make the volume $10 \mathrm{~mL}$ before $0.1 \mathrm{~mL}$ of FolinCiocalteu reagent was added. The mixture was vortexed for $5 \mathrm{~min} ; 2 \mathrm{~mL}$ of $20 \%$ sodium carbonate solution was added and vortexed for 5 minutes. Ten $\mathrm{mL}$ of distilled water was added to each sample to make the total volume of $10 \mathrm{~mL}$, then the solution was kept for $30 \mathrm{~min}$ at room temperature. Absorbance was measured using spectrophotometer at a wavelength of $760 \mathrm{~nm}$ (Galvao et al. 2018). A standard curve was obtained from some diluted tannic acid concentrations under the same conditions.

\section{Determination of alkaloid content}

One hundred $\mathrm{mg}$ of sample extract was diluted in $2 \mathrm{~N}$ $\mathrm{HCl}$, shaken vigorously, and washed (3 times) with $10 \mathrm{~mL}$ of chloroform in a funnel separator. The chloroform phase was discarded, and the solution was neutralized by adding $0.1 \mathrm{~N} \mathrm{NaOH}$ before adding BCG (bromocresol green) solution, and $5 \mathrm{~mL}$ of phosphate buffer. The mixture was further treated with $5 \mathrm{~mL}$ of chloroform to bring the volume to $10 \mathrm{~mL}$, and stirred with a magnetic stirrer (500 
$\mathrm{rpm}, 15 \mathrm{~min}$ ). The extraction was conducted twice and the chloroform was evaporated with nitrogen gas. The absorbance was measured at a wavelength of $470 \mathrm{~nm}$ using the spectrophotometer (Ajanal et al. 2012). A standard calibration curve was obtained from various diluted concentrations of quinine.

\section{Determination of phenol content}

Fifty mg of sample extract was weighed and added to $0.5 \mathrm{~mL}$ of Folin-Ciocalteu reagent and $7.5 \mathrm{~mL}$ of distilled water. The mixture was kept at room temperature for 10 min. Later, $1.5 \mathrm{~mL}$ of $20 \% \mathrm{Na}_{2} \mathrm{CO}_{3}$ solution was added and ultimately the volume was made up to $10 \mathrm{~mL}$ with distilled water. This was followed by vigorous shaking and then solution was allowed to stand for 2 hours. The resulting solution was diluted (25 times) then the absorbance was measured at a wavelength of $760 \mathrm{~nm}$ using the spectrophotometer (Vador et al. 2012). A standard calibration curve was obtained from various diluted concentrations of gallic acid.

\section{Determination of steroid content}

In order to Determine steroid as $\beta$-sitosterol equivalents, thin layer chromatography (TLC) method (Bhawani et al 2010) was used. One hundred mg of sample extract was dissolved in $1 \mathrm{~mL}$ ethanol, after which the mixture was homogenized. The $5 \mu \mathrm{L}$ sample was spotted on silica gel $60 \mathrm{~F} 254$, including the standard beta sitosterol. Silica gel 60 F254 was put in the chamber containing the mobile phase of toluene: ethyl acetate (80:20). The mobile phase was eluted and traveled upwards with the sample component. The TLC plate was lifted and dried then sprayed with Lieberman Bucard reagent, then dried in the oven at $110^{\circ} \mathrm{C}$ for $2 \mathrm{~min}$. The silica gel plate was visualized under UV light at a wavelength of $340 \mathrm{~nm}$.

\section{Cytotoxicity examination}

Investigation of the cytotoxicity of the ethanolic extract of $B$. scandens leaves was conducted at LPPT University of Gadjah Mada, Central Java, from May to August 2019. The sample extract was tested for in vitro cytotoxicity against HeLa (human cervical cancer) and T47D (breast cancer) cell culture lines using Microculture Tetrazolium Salt (MTT) assay. The cell viability can be detected by measuring the activity of the mitochondrial dehydrogenase enzymes, whereby the MTT salt was reduced to watersoluble purple formazan (Mas et al. 2010). Aliquots of various concentrations $(800 \mu \mathrm{g} / \mathrm{mL}, 400 \mu \mathrm{g} / \mathrm{mL}, 200$ $\mu \mathrm{g} / \mathrm{mL}, 100 \mu \mathrm{g} / \mathrm{mL}, 50 \mu \mathrm{g} / \mathrm{mL}, 25 \mu \mathrm{g} / \mathrm{mL}, 10 \mu \mathrm{g} / \mathrm{mL}, 5$ $\mu \mathrm{g} / \mathrm{mL}, 2.5 \mu \mathrm{g} / \mathrm{mL}$ and $1.25 \mu \mathrm{g} / \mathrm{mL}$ ) were prepared from the concentrated sample extract by dissolving in $0.25 \%$ DMSO. The HeLa and T47D cell culture lines were washed and treated with $0.01 \mathrm{~mL}$ MMT per well. Plates were incubated in an incubator set at $37^{\circ} \mathrm{C}$ with $5 \% \mathrm{CO}_{2}$ for 4 hours and $100 \mu \mathrm{L}$ of the extraction buffer $(10 \%$ sodium dodecyl sulfate in $0.01 \% \mathrm{HCl}$ ) was added. After overnight incubation, the absorbance was measured at wavelength of $550 \mathrm{~nm}$ using the microplate ELISA reader (Bio-Rad). The cytotoxicity against the HeLa and T47D cells of the different extracts was shown in a log dose series, and IC50 or $50 \%$ cell death was calculated. Cytotoxicity is calculated using the following formula:

$\%$ Cytotoxicity $=[$ Control cells OD- Sample OD $] / O D$ control cells x $100 \%$

\section{Data analysis}

The quantitative and qualitative phytochemical results were presented in a descriptive method. The quantitative data were analyzed by SPSS version 19. Cytotoxicity examination results were analyzed and graphed using Microsoft Excel.

\section{RESULTS AND DISCUSSION}

\section{Phytochemical properties of Bauhinia scandens leaf extract}

The screening of phytochemicals of $B$. scandens showed several phytochemicals, including flavonoids, saponins, tannins, alkaloids, terpenoids, and steroids, and glycosides (Table 1). The leaves of B. scandens had the highest concentration for total phenols $(17.57 \pm 0.098 \%$ $\mathrm{w} / \mathrm{w})$ and saponins $(19.42 \pm 0.091 \% \mathrm{w} / \mathrm{w})$ among these phytochemicals (Table 1).

\section{Cytotoxic effect of Bauhinia scandens extract in vitro}

In determining the cytotoxic effects of $B$. scandens in vitro, we started by using the highest leaf extract concentration range of $3000 \mu \mathrm{g} / \mathrm{mL}$ to $5.85 \mu \mathrm{g} / \mathrm{mL}$. We obtained the $\mathrm{IC}_{50}$ values of $4.60 \mu \mathrm{g} / \mathrm{mL}$ for $\mathrm{HeLa}$ cells (Figure 2.A) and $5.87 \mu \mathrm{g} / \mathrm{mL}$ for T47D cells (Figure 2.Cc). When the leaf extract concentration was lowered to a range of $2000 \mu \mathrm{g} / \mathrm{mL}$ to $3.906 \mu \mathrm{g} / \mathrm{mL}$, we obtained the $\mathrm{IC}_{50}$ values of $5.18 \mu \mathrm{g} / \mathrm{mL}$ for HeLa cells (Figure 2.B) and $5.86 \mu \mathrm{g} / \mathrm{mL}$ for T47D cells (Figure 2.D). As leaf extract concentration was further lowered, from $800 \mu \mathrm{g} / \mathrm{mL}$ to1.56 $\mu \mathrm{g} / \mathrm{mL}$ it had an IC50 at $1.95 \mu \mathrm{g} / \mathrm{mL}$ against the HeLa cells (Figure 3.A) and $4.54 \mu \mathrm{g} / \mathrm{mL}$ against the T47D cells (Figure 3.B). It means that the higher concentration of the extract may lead to a lower percentage of live cells.

Table 1. Qualitative (presence or absence of active compounds) and quantitative (amount of compounds) test results of the phytochemicals in Bauhinia scandens leaves.

\begin{tabular}{lcc}
\hline Compound & Results & Content $(\%$ w/w $)$ \\
\hline Flavonoids & $(+)$ & $5.91 \pm 0.098$ \\
Saponins & $(+)$ & $19.42 \pm 0.091$ \\
Tannins & $(+)$ & $1.24 \pm 0.035$ \\
Alkaloids & $(+)$ & $1.31 \pm 0.001$ \\
Steroids & $(+)$ & $0.08 \pm 0.007$ \\
Total Phenols & $(+)$ & $17.57 \pm 0.098$ \\
Terpenoids & $(+)$ & Not quantified \\
Glycosides & $(+)$ & Not quantified \\
\hline
\end{tabular}



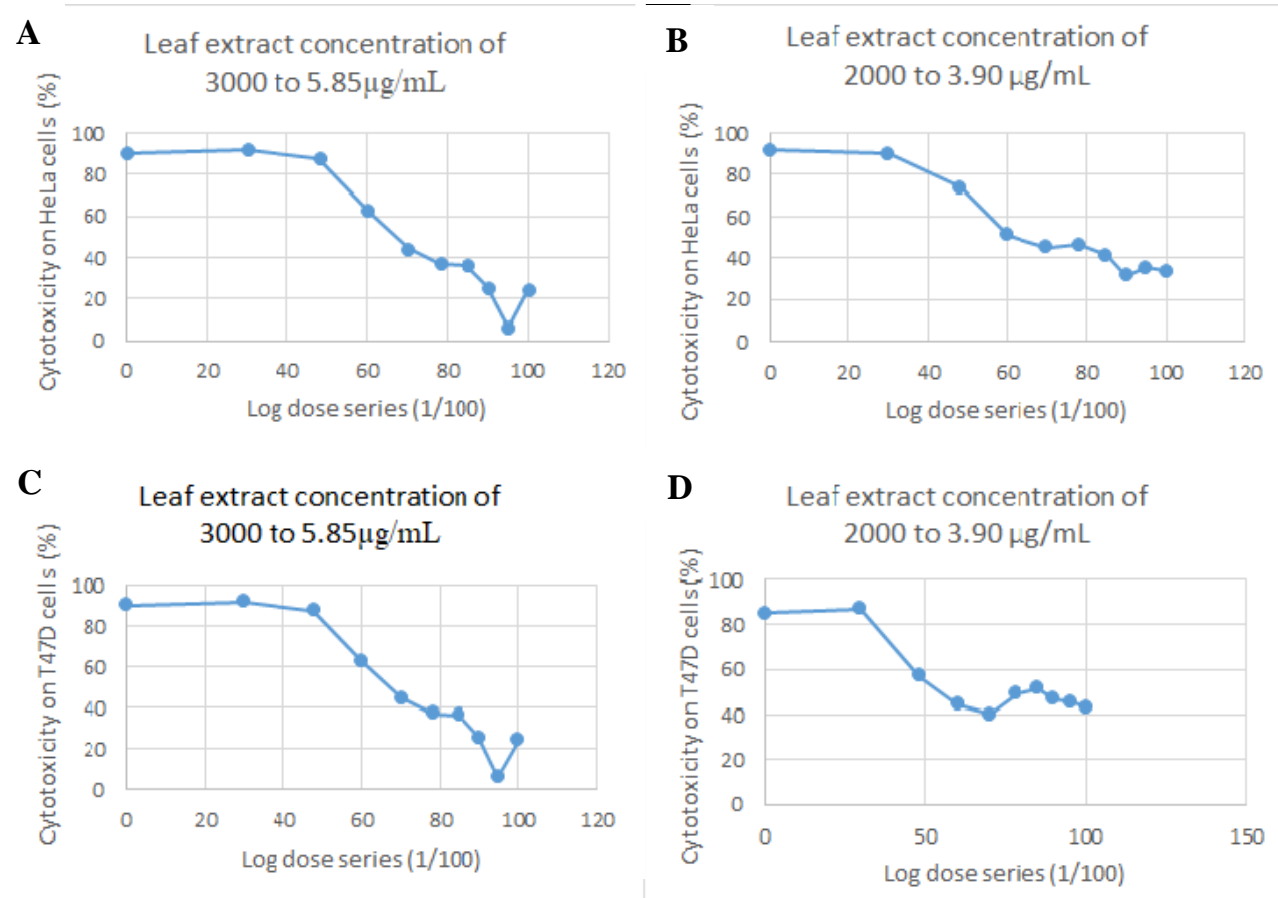

Figure 2. Cytotoxicity of Bauhinia scandens leaf extracts: A-B. Against HeLa Cells at concentration of (A) $3000 \mu \mathrm{g} / \mathrm{mL}$ to $5.85 \mu \mathrm{g} / \mathrm{mL}$ and (B) $2000 \mu \mathrm{g} / \mathrm{mL}$ to $3.90 \mu \mathrm{g} / \mathrm{mL}$; C-D. Against T47D cells at concentration of (C) $3000 \mu \mathrm{g} / \mathrm{mL}$ to $5.85 \mu \mathrm{g} / \mathrm{mL}$ and (D) $2000 \mu \mathrm{g} / \mathrm{mL}$ to $3.906 \mu \mathrm{g} / \mathrm{mL}$.

$\mathbf{A}$

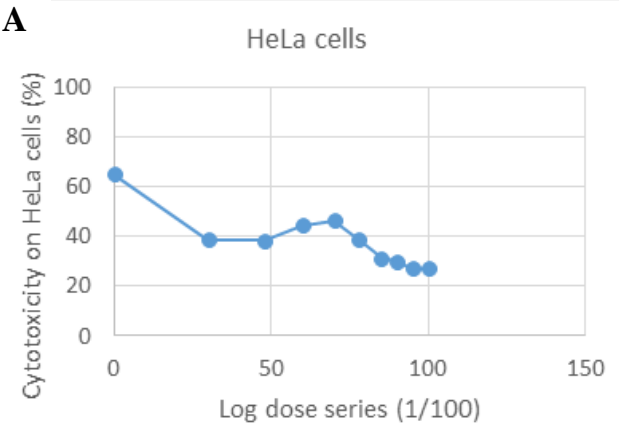

$\mathbf{B}$

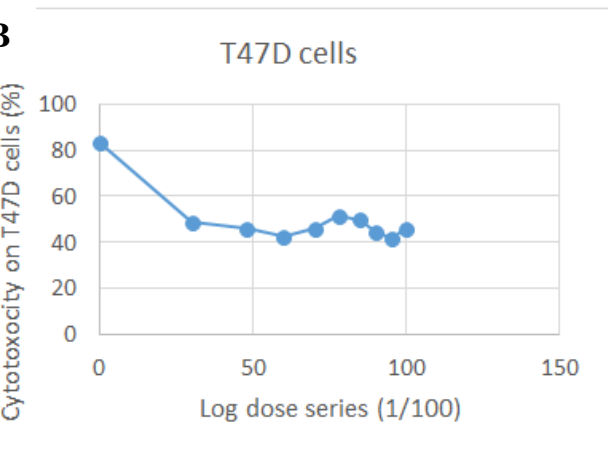

Figure 3. Cytotoxicity of Bauhinia scandens leaf extracts against: A. HeLa cells, B. T47D cells

\section{Discussion}

Phytochemicals are important for human health and have potential to treat various diseases (Pandiagan et al. 2019). Our study confirmed that the leaves of B. scandens contain significant amount of phytochemicals, such as flavonoids, saponins, alkaloids, steroids, and phenols. The leaves of B. scandens have more flavonoids $(5.91 \pm 0.098 \%$ w/w) (Table 1), than those reported for the leaves of $B$. racemosa $(0.04 \pm 0.09 \% \mathrm{w} / \mathrm{w})$ and $B$. purpurea $(0.09 \pm 0.11 \%$ w/w) (Sharanabasappa et al. 2007). Flavonoids are involved in anticancer activities, such as inhibition of cell growths, protein kinase activities, angiogenesis, and induction of apoptosis by activating p53 protein and their target genes (Plaumann et al. 1996). Several studies reported that single compound of flavonoids has been proven to possess strong cytotoxicity such asdiosmetin and diosmetin 7-O- $\beta$-D-glucopyranoside isolated from the flowers of Chrysanthemum morifolium Ramat. 'huaiju' cv. nov. (family Asteraceae) against Colon205, with their IC50 values being 96.9 and $82.9 \mu \mathrm{M}$, respectively (Xie et al. 2009); apigenin, chrysin, and luteolin compounds against cervical cancer (Sak 2014); and 3,3',4' -trihydroxy(3',4"'-dihydro-3', 4',-dihydroxy)-2', 2'"-

dimethylpyrano-(5,',6":7,8)-flavone isolated from Centaurea scoparia (family Asteraceae) agent against HeLa cells, with an IC50 of $0.079 \mu \mathrm{M}$ (Ahmed and Kamel 2014). Because of its high flavonoid content, B. scandens leaves could potentially be developed as an anticancer agent. This study, however, did not include isolation of the individual active compound of the flavonoids. 
The leaves of $B$. scandens contain more saponins $(19.42 \pm 0.091 \% \mathrm{w} / \mathrm{w})$ (Table 1) than those reported in Citrus leaves, such as $C$. paradisii $(0.89 \pm 0.01 \% \mathrm{w} / \mathrm{w}), C$. grandis $(0.87 \pm 0.06 \% \mathrm{w} / \mathrm{w}), C$. reticulata $(0.81 \pm 0.01 \%$ $\mathrm{w} / \mathrm{w}), \quad C$. aurantifolia $(0.64 \pm 0.01 \% \mathrm{w} / \mathrm{w}), C$. sinensis $(0.43 \pm 0.01 \% \quad \mathrm{w} / \mathrm{w})$ and $C$. limon $(0.34 \pm 0.02 \% \quad \mathrm{w} / \mathrm{w})$ (Ezeabara et al. 2014). Several studies reported that saponins have been proven to possess strong cytotoxicities. Saponins can activate the intrinsic or extrinsic apoptotic pathways, hold the cell cycle, autophagic dynamics, and inhibit angiogenesis and metastasis (Plaumann et al. 1996; Sobolewska et al. 2020). Podolak et al. (2010) reported that the cytotoxic effects of saponins may be due to either apoptosis inducement or nonapoptotic cell death stimulation. Cytotoxic effects of saponins were also studied by Alam et al. (2017) who reported that saponins from fruit, bark, and leaves of traditional medicinal plant Zanthoxylum armatum (family Rutaceae) have potential cytotoxic effect on breast and colorectal cancer cell lines through a mechanism involving apoptosis.

Tannin concentration in B. scandens leaves (1.24 \pm $0.0355 \mathrm{w} / \mathrm{w}$ ) (Table 1) is lower than those reported in Turkish wine, beer and black tea $(2.76-6.54 \%$ w/w, 8.03$6.59 \% \mathrm{w} / \mathrm{w}$ and $6.20-8.33 \% \mathrm{w} / \mathrm{w}$, respectively) (Tinkilic and Uyanik 2001). Tannins are known to induce death of cancer cells in various types of cancer. Several studies reported that single compound of tannins has been proven to possess strong cytotoxicities. Hong et al. (2011) reported that the extracted hydrolyzable tannin from the bark of Rhizophora apiculata (family Rhizophoraceae) has cytotoxicity effects on HepG2 cancer cells at IC50 of 12.26 $\mu \mathrm{g} / \mathrm{mLs}$. Tannic acid is involved in the induction of apoptosis in human glioma Hs 683 cells by increasing reactive oxygen species (ROS) molecules, which are responsible for inducing apoptosis in cancer cells by generating transitional pore opening in mitochondria (Zhang et al. 2018). Tannins have also been applied as antidiarrhea, hemostatic, anti-bacterial, antioxidant, antiinflammatory, anti-hemorrhoidal and antiseptic compounds (Ashok and Upadhyaya 2012; Khanbabaee and Van Reeb 2001). In this study, however, we did not isolate tannin from $B$. scandens leaves and we did not evaluate cytotoxic activity from the isolated tannins.

The concentration of alkaloids from $B$. scandens $(1.31 \pm$ $0.001 \% \mathrm{w} / \mathrm{w})($ Table 1) is found to be higher than the alkaloids in Actinidia arguta (family Actinidiaceae) leaves (0.95 mg/g or $0.095 \%$ w/w) (Liu and Liu 2015). Several studies also reported that single compound of alkaloids has been proven to possess strong cytotoxicities, such as aporphine isolated from Alphonsea sclerocarpa (family Annonaceae) showed antioxidant and anti-cancer activities upon testing with K562 (CML-chronic myeloid Leukaemia blood cancer) cells (Joshi DSD et al. 2018). The total and individual alkaloids from Broussonetia papyrifera (family Moraceae) fruits have higher activities on BEL-7402 and HeLa cell lines with low IC50 values (6.61-47.41 and 5.97$40.17 \mu \mathrm{g} / \mathrm{mL}$, respectively) (Pang et al. 2014). The total alkaloids (400 $\mu \mathrm{g} / \mathrm{mL}$ ) of Eucalyptus camaldulensis (family Myrtaceae) could reduce the cell viability of both breast cancer cell line Michigan Cancer Foundation-7 (MCF-7) and nontumorigenic fetal hepatic cell line (WRL-68) to $45.25 \pm 2.20 \%$ and $92.00 \pm 1.55 \%$, respectively, and the IC50was $375.50 \mu \mathrm{g} / \mathrm{mL}$ for MCF-7(Al-Marzook and Omran 2017). The total alkaloids isolated from different parts of Solanum pseudocapsicum (family Solanaceae) mainly at its leaves contain the most potent against human adenocarcinoma (HT-29) cells compared to the other plant organs (Vijayan et al. 2004). Therefore, we think that the alkaloids of phytochemicals in B. scandens leaves also contribute to cytotoxic activity against HeLa and T47D cells.

The leaves of $B$. scandens contain steroids at a concentration of $0.08 \pm 0.007 \% \mathrm{w} / \mathrm{w}$ (Table 1). These compounds seem to play an important role in treating cancer. Several studies also reported that isolated steroids has been proven to possess strong cytotoxicities. Guan et al. (2016) found that the two steroids such as 'compound 4' showed potential antitumor activities against HeLa, KB cell lines $(\mathrm{IC} 50=3.65-6.90 \mu \mathrm{M})$ and 'compound 6' showed potential antitumor activities against HeLa, BGC-823, KB, A549, and HCT-8 cell lines (IC50 = 2.40-9.05 $\mu \mathrm{M}$ ). Katja et al. (2011) reported that three cytotoxic steroids such as stigmasterol (1), stigmast-5-en-3 $\beta$-ol (2) and $\beta$-sitosterol-3O-acetate (3) isolated from the stem bark of Chisocheton cumingianus showed cytotoxicity activity against P-388 murine leukemia cells with IC50 values of 12.4, 60.8, and $>100 \mu \mathrm{g} / \mathrm{mL}$, respectively. In this study, we also did not isolated steroids from $B$. scandens leaves and we did not evaluate cytotoxic activity from the isolated steroids.

The total phenol that was detected and quantified in $B$. scandens leaves $(17.57 \pm 0.098 \% \mathrm{w} / \mathrm{w})$ (Table 1) is higher than those found in the leaves of $B$. racemosa $(0.55 \pm 0.36 \%$ w/w) and $B$. purpurea $(0.48 \pm 0.57 \%$ w/w) (Sharanabasappa et al. 2007). The leaves of B. scandens was also found to have terpenoids and glycosides, but their concentrations were not quantified (Table 1). Macwan et al. (2016) reported that glycosides extracted from leaves of Corchorus trilocularis and seeds of Corchorus aestuans (family Malvaceae) have cytotoxic activity against K-562 with IC50 of $67.44 \mu \mathrm{g} / \mathrm{mL}$ and $37.09 \mu \mathrm{g} / \mathrm{mL}$, respectively. Terpenoids were also shown in a previous study to have anticancer activity (Prakash 2018). The presence of terpenoids and glycosides in $B$. scandens leaves makes it a good anticancer source candidate.

We have determined that phytochemicals detected in $B$. scandens leaves have cytotoxic activity although we did not evaluate every single compound. The extract of $B$. scandens leaves showed cytotoxic activity with a low IC50 value of $1.95 \mu \mathrm{g} / \mathrm{mL}$ against HeLa cells and $4.54 \mu \mathrm{g} / \mathrm{mL}$ against T47D cells (Fig 3a. and 3b). Compounds in leaf extracts could have synergistic and antagonistic activities (Yin et al. 2014). Compared to having a single component, the presence of several interacting compounds could have a cumulative effect. In this study, the phytochemicals in $B$. scandens leaves could have synergistic interactions, making ita potentially good candidate for anticancer agent screening. However, it must be emphasized that we have not isolated the individual active compounds in this study and as expected, active components are generally more toxic, as the extracts may contain a variety of secondary 
compounds that can reduce or modulate the activities (Wink 2015). Further research should be pursued to isolate bioactive compounds in $B$. scandens leaves, determine the activities of these compounds, and investigate further the anticancer potential of this species.

\section{ACKNOWLEDGEMENTS}

The authors are grateful to UIN Walisongo, Semarang, Indonesia for the continuous support, and the Directorate of Islamic Higher Education of Religious Affair Ministry, Indonesia for funding the study. The authors declare that there is no conflict of interest.

\section{REFERENCES}

Ahmed SA, Kamel EM. 2014. Cytotoxic activities of flavonoids from Centaurea scoparia. Sci World J 2014: 274207. DOI: 10.1155/2014/274207.

Ajanal M, Gundkalle MB, Nayak SU. 2012. Estimation of total alkaloid in Chitrakadivati by UV-Spectrophotometer. Ancient Sci Life 31 (4): 198-201.

Alam F, Saqib QNU, Waheed A. 2017. Cytotoxic activity of extracts and crude saponins from Zanthoxylum armatum DC. against human breast (MCF-7, MDA-MB468) and colorectal (Caco-2) cancer cell lines. BMC Complement Altern Med 17 (1): 368 DOI: 10.1186/s12906017-1882-1.

Al-Marzook FA, Omran R. 2017. Cytotoxic activity of alkaloid extracts of different plants against breast cancer cell line. Asian J Pharm Clin Res 10 (7): 168-171.

Ashok PK, Upadhyaya K. 2012. Tannins are astringent. J Pharmacog Phytochemi 1 (3): 45-50.

Baba SA, Malik SA. 2014. Determination of total phenolic and flavonoid content, antimicrobial and antioxidant activity of root extract of Arisaema jacquemontii Blume. J Taibah Univ Sci 9: 449-454.

Bandyopadhyay S, Lakshminarasimhan P. 2017. Epitypification Bauhinia scandens (Leguminosae: Cercidoideae). J Econ Taxon Bot 41: 137138.

Bhawani SA, Sulaiman O, Hashim R, Mohamad MN. 2010. Thin-layer chromatography analysis of steroids: a review. Trop J Pharm Res 9 (3): 301-313.

Borikar VL, Jangde CR, Rekhe DS, Phillip P. 2009. Study of analgesic activity of Bauhinia racemosa Lam. in rat. Vet World 2 (4): 135-136.

Campos JKL, Araujo CSF, Araujo TFS, Santos AFS, Teixeira JA, Lima VLM, Coelho LCBB. 2016. Anti-inflammatory and anti-nociceptive activities of Bauhinia monandra leaf lectin. Biochimie 2: 62-68.

Ezeabara CA, Okeke CU, Aziagba BO, Ilodibia, CV, Emeka AN. 2014 Determination of saponin content of various parts of six Citrus species. Int Res J Pure Appl Chem 4: 137-143.

Faisal R, Shinwari L, Aziz I, Khalil AT. 2019. Therapeutic and adverse effect of commonly used medicinal plants: standardization and quality assurance. Proc Pak Acad Sci 56 (3): 1-9.

Galvao MAM, de Arruda AO, Bezerra ICF, Ferreira MRA, Soares LAL. 2018. Evaluation of the Folin-Ciocalteu method and quantification of total tannins in stem barks and pods from Libidibia ferrea (Mart. ex Tul) L. P. Queiroz. Braz Arch Biol Technol 61: 1-20.

Guan YY, Li SZ, Lei PS. 2016. Synthesis and cytotoxic activity of two steroids: icogenin aglycone analogs. J Asian Nat Prod Res 5: 481-488.

Harborne JB. 1973. Phytochemical Methods: A Guide to Modern Techniques of Plant Analysis. Chapman A \& Hall, London.

Hazra AG, Chatterjee P. 2008. A nontoxic anti-tumour compound from the leaves of Bauhinia scandens characterized as 1-0-alkyl glycerol by gas-liquid chromatography and evaluation of its anti-tumour property by brine shrimp bioassay. Indus Crops Prod 27: 39-43.

Hong LS, Ibrahim D, Kassim J. 2011. Assessment of in vivo and in vitro cytotoxic activity of hydrolysable tannin extracted from Rhizophora apiculata barks. World J Microbiol Biotechnol 27 (11): 2737-2740.

Hossain MS, Niloy SA, Hosen A, Ul Islam MA, Islam Z, Das S, Hassan MA, Mahmudul Islam AFM, Rana MS. 2017. Antioxidant activities and HPLC-DAD based phenolic content determination of Bauhinia scandens. Brit J Pharm Res 14: 1-4.

Hou L, Larsen. 1996. Caesalpiniaceae (Leguminosae-Caesalpinioideae). Flora Malesiana 12 (2): 409-730.

Joshi DSDS, Amgoth C, Narayana S, Padmavathi CH, Madhavi J, Satya AK. 2018. Antioxidant and anticancer activities of an aporphine alkaloid isolated from Alphonsea sclerocarpa. J Phytopharmacol 7: 51-55.

Katja DG, Farabi K, Nurlelasari, Harneti D, Maharani R, Julaeha E, Hidayat AT, Mayanti T, Supratman U. 2017. Cytotoxic steroids from the stem bark of Chisocheton cumingianus (Meliaceae). Molekul 12 (1): $1-7$.

Khanbabaee K, van Reeb T. 2001. Tannins: classification and definition. Nat Prod Rep 18 (6): 641-649.

Lianah, Idris F, Krisantini. 2019. Short communication: analysis of the chemical constituents and micromorphology of Bauhinia scandens using SEM-EDS techniques. Biodiversitas 20 (7): 2055-2060.

Lianah. 2016. Morphological characteristic of a unique 'chain tree' Bauhinia scandens Willd (Caesalpinioideae, Leguminosae) from Pager Wunung Conservation Park, Central Java, Indonesia. J Trop Crop Sci 3 (2): 56-60.

Liu Y, Liu C. 2015. Determination of total alkaloids in different parts of Actinidia arguta by spectrophotography. Intl Conf Mater Environ Biol Eng 127-130.

Macwan CP, Patel NM, Suhagia BN, Patel VP, Patel MA. 2016. In-vitro cytotoxic activity of glycosides from leaves and seeds of Corchorus species against K-562 and Vero cell line. Eur J Pharm Med Rese 3 (5): 511-516.

Maitra A, Chatterjee P, Bhattacharya S. 1991. Possible anti-carcinogenic activity of the herbal extract of Bauhinia anguina Roxburgh. Cell Chromosome Res 14: 35-40.

Mas S, Gao W, Zhang F, Liu C. 2010. Chemical study and medical application of saponin as anticancer agents. www.ncbi.nlm.nih.gov

Ministry of Health of the Republic of Indonesia. 2019. Hari Kanker Sedunia 2019. www.depkes.go.id. [Indonesian]

Mishra A, Sharma AK, Kumar S. Saxena AK, Pandey AK. 2013. Bauhinia variegata leaf extracts exhibit considerable antibacterial, antioxidant, and anticancer activities. BioMed Res Intl 2013: 915436. DOI: $10.1155 / 2013 / 915436$.

Pandey S. 2017. In vivo antitumor potential of extract from different parts of Bauhinia variegata Linn. against b16f10 melanoma tumor model in c57bl/6 mice. Appl Cancer Res 37: 33. DOI: 10.1186/s41241-0170039-3.

Pandiagan D, Silalahi M, Dapas F, Kandou F. 2019. Diversity of medicinal plants and their uses by the Sanger tribe of Sangihe Islands, North Sulawesi, Indonesia. Biodiversitas 20 (3): 611-621.

Pang SQ, Wang GQ, Lin JS, Diao Y, Xu R. 2014. Cytotoxic activity of the alkaloids from Broussonetia papyrifera fruits. Pharm Biol 52 (10): 1315-1319.

Plaumann B, Frirsche M, Rimpler H, Brandner G. 1996. Flavonoids activate wild-type p53. Oncogene 13 (8): 1605-1614.

Podolak I, Galanty A, Sobolewska D. 2010. Saponins as cytotoxic agents: a review. Phytochem Rev 9 (3): 425-474.

Prakash V. 2018. Terpenoids ad cytotoxic compounds: a perspective. Pharmacol Rev 12 (14): 166-176.

Roy, S., Zamir Uddin, M., Abul Hassan, M. and Matiur Rahman, M. 2008. Medico-botanical report on the Chakma community of Bangladesh. Bangladesh J. Plant Taxon., 15(1): 67-72Sak K. 2014. Cytotoxicity of dietary flavonoids on different human cancer types. Pharmacog Rev 8 (6): 122-146.

Sharanabasappa GK, Santosh MK, Shaila D, Seetharam YN, Sanjeevarao I. 2007. Phytochemical Studies on Bauhinia racemosa Lam., Bauhinia purpurea Linn. and Hardwickia binata Roxb. E J Chem 4 (1): 21-31.

Shreedhara CS, Vaidya CP, Vagdevi HM, Latha KP, Muralhrishna KS, Krupanidhi AM. 2009. Screening of Bauhinia purpurea Linn. for analgesic and anti-inflammatory activities. Indian J Pharmacol 41: 7579.

Singh A, Singh N, Pabla D. 2019. A review on medicinal uses of Bauhinia variegata Linn. Pharm Tutor 7 (6): 12-17.

Sobolewska D, Galanty A, Grabowska K, Makowska-Was J, Wro'belBiedrawa D, Podolak I. 2020. Saponins as cytotoxic agents: an update (2010-2018). Part I - steroidal saponins. Phytochemi Rev 19: 139189.

Sofowora A. 1993. Medicinal Plants and Traditional Medicines in Africa. Chichester John Willey \& Sons, New York. 
Tinkilic N, Uyanik A. 2001. Spectrophotometric determination of the tannin contents of various Turkish black tea, beer, and wine samples. Intl J Food Sci Nutr 52 (3): 289-294.

Trease GE, Evans WC. 1989. A Textbook of Pharmacognosy. Bailliere Tindall Ltd, London.

Vador N, Vador B, Hole R. 2012. Simple spectrophotometric methods for standardizing Ayurvedic formulation. Indian J Pharm Sci 74 (2): 161163.

Vijayan P, Vijayaraj P, Setty PHC. 2004. The cytotoxic activity of the total alkaloids isolated from different parts of Solanum pseudocapsicum. Biol Pharm Bull 27 (4): 528-530.
Wink M. 2015. Modes of action of herbal medicines and plant secondary metabolites. Medicines (Basel) 2 (3): 251-286

Xie Y-Y, Yuan D, Yang J-Y, Wang LH, Wu CF. 2009. Cytotoxic activity of flavonoids from the flowers of Chrysanthemum morifolium on human colon cancer Colon205 cells. J Asian Nat Prod Res 11 (9): 771-778.

Yin N, Ma W, Pei J, Ouyang Q, Tang C, Lai L. 2014. Synergistic and antagonistic drug combinations depend on network topology. PLoS ONE 9 (4): e93960. DOI: 10.1371/journal.pone.0093960

Zhang J, Chen D, Han DM, Cheng YH, Dai C, Wu XJ, Che FY, Heng $\mathrm{XY}$. Tannic acid-mediated induction of apoptosis in human glioma Hs 683 cells. Oncol Lett 15 (5): 6845-6850. 